\title{
Phosphorylation regulates human T-cell leukemia virus type I Rex function
}

\author{
Matthew Kesic ${ }^{1,2}$, Rami Doueiri ${ }^{1,2}$, Michael Ward ${ }^{5}$, O John Semmes ${ }^{5}$ and \\ Patrick L Green*1,2,3,4
}

\begin{abstract}
Address: ${ }^{1}$ Center for Retrovirus Research, The Ohio State University, Columbus, OH 43210, USA, ${ }^{2}$ Department of Veterinary Biosciences, The Ohio State University, Columbus, OH 43210, USA, ${ }^{3}$ Department of Molecular Virology, Immunology, and Medical Genetics, The Ohio State University, Columbus, OH 43210, USA, ${ }^{4}$ Comprehensive Cancer Center and Solove Research Institute, The Ohio State University, Columbus, OH 43210, USA and ${ }^{5}$ Department of Microbiology and Molecular Cell Biology and Center for Biomedical Proteomics, Eastern Virginia Medical School, Norfolk, Virginia 235070, USA
\end{abstract}

Email: Matthew Kesic - kesic.1@osu.edu; Rami Doueiri - doueiri.1@osu.edu; Michael Ward - wardmd@evms.edu; O John Semmes - semmesoj@evms.edu; Patrick L Green* - green.466@osu.edu

* Corresponding author

Published: 17 November 2009

Retrovirology 2009, 6:105 doi:10.1186/1742-4690-6-105

This article is available from: http://www.retrovirology.com/content/6/1/105

(C) 2009 Kesic et al; licensee BioMed Central Ltd.

This is an Open Access article distributed under the terms of the Creative Commons Attribution License (http://creativecommons.org/licenses/by/2.0), which permits unrestricted use, distribution, and reproduction in any medium, provided the original work is properly cited.

\begin{abstract}
Background: Human T-cell leukemia virus type I (HTLV-I) is a pathogenic complex deltaretrovirus, which is the causative agent of adult T-cell leukemia/lymphoma (ATL) and HTLVI-associated myelopathy/tropical spastic paraparesis. In addition to the structural and enzymatic viral gene products, HTLV-I encodes the positive regulatory proteins Tax and Rex along with viral accessory proteins. Tax and Rex proteins orchestrate the timely expression of viral genes important in viral replication and cellular transformation. Rex is a nucleolar-localizing shuttling protein that acts post-transcriptionally by binding and facilitating the export of the unspliced and incompletely spliced viral mRNAs from the nucleus to the cytoplasm. HTLV-I Rex (Rex-I) is a phosphoprotein and general protein kinase inhibition correlates with reduced function. Therefore, it has been proposed that Rex-I function may be regulated through site-specific phosphorylation.

Results: We conducted a phosphoryl mapping of Rex-I over-expressed in transfected $293 \mathrm{~T}$ cells using a combination of affinity purification and liquid chromatography tandem mass spectrometry. We achieved $100 \%$ physical coverage of the Rex-I polypeptide and identified five novel phosphorylation sites at Thr-22, Ser-36, Thr-37, Ser-97, and Ser-106. We also confirmed evidence of two previously identified residues, Ser-70 and Thr-174, but found no evidence of phosphorylation at Ser-177. The functional significance of these phosphorylation events was evaluated using a Rex reporter assay and site-directed mutational analysis. Our results indicate that phosphorylation at Ser-97 and Thr-174 is critical for Rex-I function.
\end{abstract}

Conclusion: We have mapped completely the site-specific phosphorylation of Rex-I identifying a total of seven residues; Thr-22, Ser-36, Thr-37, Ser-70, Ser-97, Ser-106, and Thr-174. Overall, this work is the first to completely map the phosphorylation sites in Rex-I and provides important insight into the regulation of Rex-I function. 


\section{Background}

Human T-cell leukemia virus types 1-4 are related complex retroviruses that are members of the genus Deltaretrovirus [1]. HTLV-1 and HTLV-2 are the most prevalent worldwide, whereas HTLV-3 and HTLV-4 were discovered recently in a limited number of individuals in Africa [2-4]. Of the HTLV isolates, only HTLV-1 infection has been clearly linked to the development of adult T-cell leukemia/lymphoma (ATL), an aggressive CD4+ T-lymphocyte malignancy, and various lymphocyte-mediated inflammatory diseases such as HTLV-1-associated myelopathy/ tropical spastic paraparesis (HAM/TSP) [5-7]. However, a few cases of atypical hairy cell leukemia or neurologic diseases have been associated with HTLV-2 infection [8-12]. Although the difference in pathology between HTLV-1 and HTLV-2 has yet to be elucidated, it likely results from differential activities of the regulatory and accessory proteins.

In addition to the typical structural and enzymatic retroviral genes gag, pol, and env, HTLV encodes two trans-regulatory genes, $\operatorname{tax}$ and $r e x$, which are essential for efficient viral replication/transformation, as well as several accessory genes important for viral infection and persistence in vivo [1]. The viral oncoprotein Tax increases the rate of transcription from the viral promoter located in the $5^{\prime}$ long terminal repeat (LTR) [13-15] and modulates the transcription and activity of numerous cellular genes involved in cell growth, cell cycle control, DNA repair, and cell differentiation [16-20]. The pleiotropic effects of Tax make it essential for efficient viral replication as well as cellular transformation and oncogenesis [21-23].

HTLV-1 Rex (Rex-1) is a nuclear-localizing and shuttling phosphoprotein that acts post-transcriptionally by preferentially binding, stabilizing, and selectively exporting the unspliced and incompletely spliced viral mRNAs from the nucleus to the cytoplasm, thus controlling expression of the structural and enzymatic proteins that are essential for production of viral progeny [24-26]. Therefore, it has been proposed that Rex- 1 regulates the switch from the early latent phase to the late productive phase of HTLV infection. Rex-1 binds viral RNAs via a cis-acting RNA sequence termed the Rex-response element (RxRE), which is located in the $\mathrm{R}$ region of the viral LTR [27]. Mutational analysis of Rex-1 has identified several critical domains including an arginine-rich N-terminal sequence that functions as an RNA binding domain (RBD) that overlaps with a nuclear localization signal (NLS), a leucine-rich central core activation domain that contains a nuclear export signal (NES), two flanking Rex-Rex multimerization domains, and a C-terminal stability domain [28-37].

Phosphorylation is a well known reversible regulatory event that controls the activity/function of proteins in eukaryotic cells [38]. It has been demonstrated that both Rex- 1 and Rex- 2 are phosphoproteins, and that this modification is critical for their function [26,39-42]. One study investigating the possible relationship of Rex-1 function and phosphorylation showed that treatment of HTLV-1 infected cells with the protein kinase $\mathrm{C}$ inhibitor $\mathrm{H}-7$ [1(5-isoquinolinyl-sulfonyl)-2-methylpiperazine] specifically blocked cytoplasmic accumulation of Rex-dependent gag-pol mRNA [40]. The same group reported that Rex1 is phosphorylated on Ser-70, Ser-177, and Thr-174, with Ser-70 phosphorylation being 12-O-tetradecanoyl-phorbol-13-acetate (TPA)-dependent [39]. However, a complete phosphorylation map and the identification of the key residues required for function have yet to be elucidated.

In this study, we combined liquid chromatography tandem mass spectrometry (LC-MS/MS) analysis [43] of affinity-purified Rex-1 protein in combination with substitution mutational analysis to identify and functionally characterize key phosphorylation sites. The LC-MS/MS analysis achieved $100 \%$ coverage of the Rex-1 sequence and revealed five novel phosphorylation sites. We also identified two specific amino acid phosphorylation events found to be critical for Rex-1 function (Ser-97 and Thr174). Overall, this work highlights the importance of phosphorylation and how it regulates the biological properties of Rex-1, ultimately controlling the distribution of viral gene expression and productive viral replication.

\section{Results}

Functional Domains of HTLV-I Rex

Mutational analyses permitted the assignment of functional properties to distinct domains of the Rex-1 protein (Fig. 1A). In addition to the characterized nuclear localization signal/RNA binding domain, central core activation domain, two multimerization domains, and the newly identified C-terminal stability domain, three phosphorylation sites have been identified at Ser-70, Ser-177, and Thr-174 by the use of reverse-phase HPLC and sequential Edman degradation [39]. However, this approach only provided limited mapping coverage of Rex1 and the functional relevance of the identified sites were not addressed. To date, no further studies have examined the possibility of other phosphorylation events or the effect of these post-translational modifications on Rex-1 function.

\section{Expression and Detection of Biological Active Affinity S- tagged Rex-I}

To identify the phosphorylated amino acid residues of Rex-1, we employed a tandem affinity purification approach of Rex-1 that was over expressed in mammalian cells. The S-tagged Rex-1 vector (S-Rex-1) expressed fulllength Rex-1 protein fused to amino-terminal $\mathrm{His}_{6}$ and S- 


\section{A}

Nuclear Localization Signal (NLS)
RNA Binding Domain (RBD)

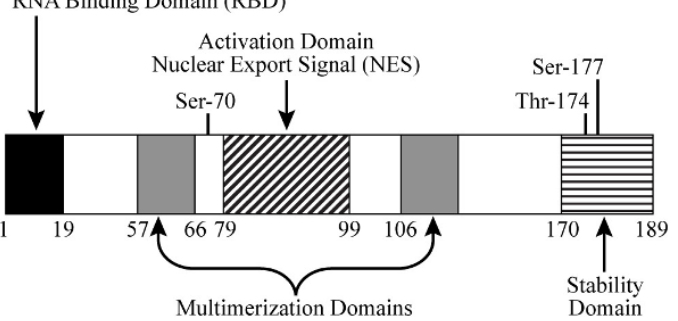

B

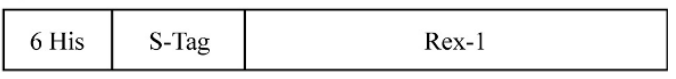

C
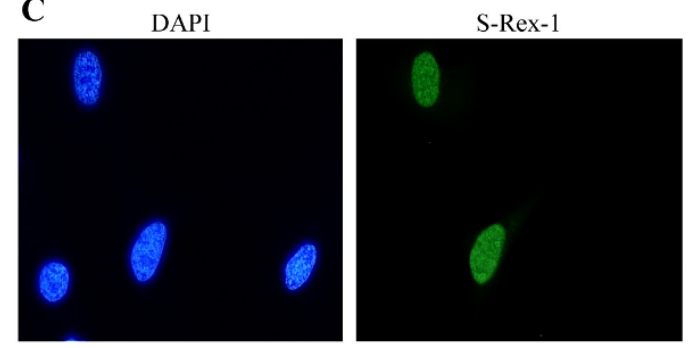

D

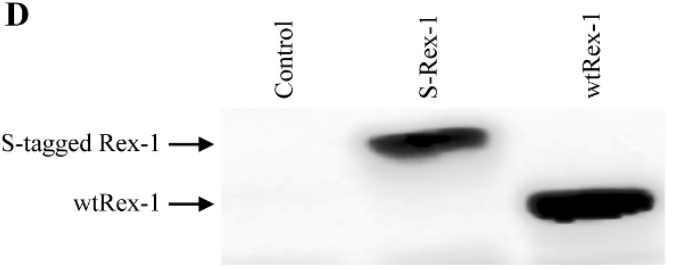

Figure I

Functional domains of HTLV-I Rex and efficient expression and detection of affinity-tagged Rex-I. (A) The functional domains of the 189 aa Rex-I are depicted in shaded boxes. The nuclear localization signal (NLS) and the RNA binding domain (RBD) are positioned within the first 19 amino acids of the protein. The activation domain and the nuclear export signal (NES) are located between residues 79 . 99. This region is flanked by the two multimerization domains; the first lies between amino acids 57-66, whereas the second spans amino acids 106-124. Recently, a C-terminal stability domain was identified spanning amino acids 170 189 [28]. Three previously identified phosphorylation sites are indicated: Ser-70, Thr-174, and Ser-177 [39]. (B) Illustration of the S-tagged Rex-I (S-Rex-I) expression vector construct (not drawn to scale). (C) To determine the subcellular localization of the S-tagged Rex-I, HeLa-Tat cells were transfected with I $\mu$ g of S-Rex-I or wtRex-I expression plasmids. At $24 \mathrm{~h}$ post-transfection, cells were stained with rabbit $\alpha$ Rex-I specific antisera (Green). Nuclei were stained with DAPI (Blue). (D) Western blot of Rex-I proteins expressed in 293T cells transiently transfected with S-Rex-I and wtRexI cDNA plasmids. Proteins as indicated were detected using rabbit $\alpha$-Rex-I specific antisera. tags (Fig. 1B). Since the HTLV-1 regulatory proteins Tax and Rex are expressed from the same mRNA in partially overlapping reading frames, a point mutation was made in the nucleotide sequence that added a stop codon in the tax-1 reading frame that left the Rex-1 amino acid sequence unchanged [44]. This mutation completely abrogated Tax-1 protein expression and function (data not shown). The S-Rex-1 expression construct was transiently transfected into $293 \mathrm{~T}$ cells, and the appropriate nuclear subcellular localization of Rex-1 was confirmed by indirect immunofluorescence microscopy (Fig. 1C). Wild type Rex-1 was shown as a single $27 \mathrm{kDa}$ band by Western blot analysis using rabbit polyclonal $\alpha$-Rex- 1 antisera (Fig. 1D). Next we determined if the S-tagged Rex1 retained its ability to function in our quantitative reporter bioassay in which HIV-1 p24 Gag production is measured and used as a read-out of Rex-1 functional activity in cultured cells. It is important to note that this assay has been a proven and accepted assay for Rex function and has been shown to directly correlate to Rex activity in the context of a molecular clone $[25,28,45]$. As shown in Figure 2A, S-Rex-1 displayed significant functional activity, although slightly lower than wtRex-1. We hypothesize that this reduced activity likely is due to the proximity of the amino terminal tag to the RNA binding domain.

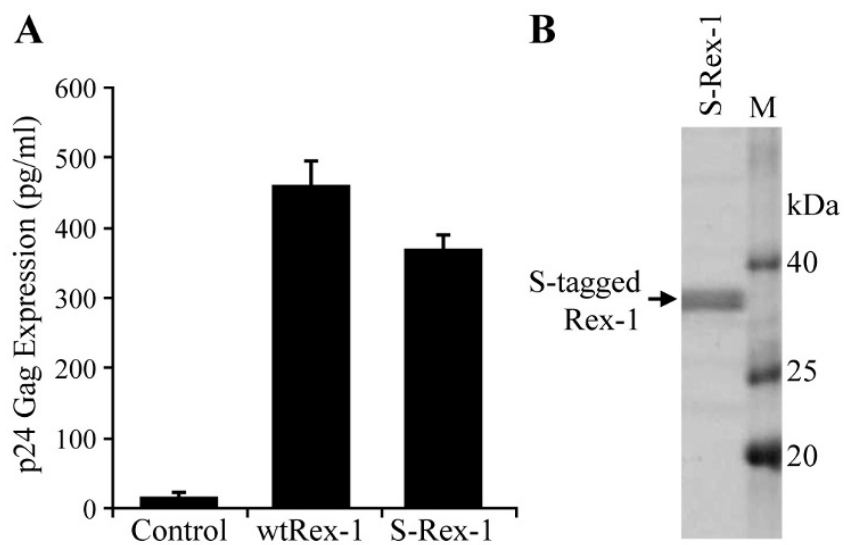

Figure 2

Functional activity and expression of S-tagged Rex-I. (A) The functional activity of S-tagged Rex-I was determined using an HIV p24 Gag reporter assay. 293T cells were transfected with $0.25 \mu \mathrm{g}$ pcTat, $0.5 \mu \mathrm{g}$ pcGagRxRE-I, $0.05 \mu \mathrm{g}$ CMV-luc, and 0.I $\mu \mathrm{g}$ of wtRex-I or S-Rex-I expression plasmids. Twenty-four hours post-transfection, cells were harvested and assayed for p24 Gag. The values represent actual p24 Gag production from a representative experiment performed in triplicate. Error bars indicate standard deviations. (B) Affinity purification of S-tagged Rex-I from mammalian cells. 293T cells were transfected with S-Rex-I and S-tagged Rex-I was purified by S-protein-agarose beads, eluted and resolved by SDS-PAGE analysis, and detected by Coomassie blue staining. 
Taken together, these data demonstrate the proper nuclear subcellular localization and efficient expression of a functionally active S-tagged Rex-1 from mammalian cells.

\section{Affinity Purification of Rex-I from Mammalian Cells} We successfully purified S-tagged Rex-1 protein from transfected $293 \mathrm{~T}$ cells using S-protein-agarose beads as described in the "Methods". This purification procedure is based on the strong affinity between the 15-amino acid Stag and the S-protein that is immobilized on the agarose beads, both of which are derived from RNase S [46]. The affinity purified S-tagged Rex-1 protein was resolved by SDS-PAGE and detected by staining with Coomassie blue (Fig. 2B). This purification process produced adequate quantities of highly purified S-tagged Rex-1 from mammalian cells and allowed the subsequent post-translational modification analysis by LC-MS/MS.

\section{Phosphopeptide Mapping of Rex-I Using LC-MSIMS}

Multiple strategies were employed to identify the phosphorylation sites within Rex-1. The affinity purified Stagged Rex-1 band was excised and treated as follows. First, the protein was subjected to trypsin enzymatic digestion. The tryptic peptides that were too large to detect were either digested further with elastase or independently digested with elastase. This combined analytical approach allowed us to obtain a detailed physical map covering $100 \%$ of the Rex-1 sequence (Fig. 3A). Our analysis identified four serine phosphorylation sites at Ser-36, Ser-70, Ser-97, and Ser-106. We also identified three phosphorylated threonine residues at Thr-22, Thr-37, and Thr-174. Figure 3B shows a representative MS/MS spectrum of the tryptic phosphopeptide, which identified phosphorylation at Thr-174. We did not identify tyrosine site-specific phosphorylation, which is consistent with an earlier report [39].

\section{Substitutional Mutational Analysis of the Identified Rex-I Phosphorylation Sites}

To determine possible regulatory roles of the seven identified phosphorylation sites, we generated single alanine amino acid substitutions and tested these Rex- 1 mutants to see if they retain their ability to function in our quantitative reporter bioassay. The Rex-1 mutants were transiently co-transfected into $293 \mathrm{~T}$ cells with pcTat and pCgagRxRE-I, along with CMV-luciferase to account for transfection efficiency. We indentified two mutants S97A and $\mathrm{T} 174 \mathrm{~A}$ that displayed significantly reduced function (Fig. 4A). Further mutational analysis of these two residues by converting them to phosphomimetic aspartic acid (S97D and T174D) restored functional activity to wtRex1 levels, which indicated that phosphorylation plays a positive functional role (Fig. 4A). Although we did not detect phosphorylation of Ser-177 in our analysis, we subjected this residue to a similar mutational and functional analysis. Our results indicated that mutant S177A or S177D maintained wild type Rex functional activity (Fig. 4A). Moreover, aspartic acid substitution of Thr-22, Ser36, Thr-37, Ser-70, or Ser-106 had no effect on protein function, which is consistent with the conclusion that phosphorylation of any of these five residues does not negatively regulate function, but is silent (data not shown). The steady state expression levels of the wild-type and mutant Rex-1 proteins were determined for each mutant by Western blot analysis and detected using rabbit polyclonal $\alpha$-Rex-1 antisera (Fig. 4B). All of the Rex-1 mutants were stably expressed. We previously showed that phosphorylation of a specific residue of Rex-2 at the carboxy terminus (Ser-151) is important for proper protein nuclear localization [28,33]. However, evaluation of the functionally disrupted substitution mutants S97A and T174A for subcellular localization revealed no difference when compared to wild-type Rex-1 (Fig. 4C). Together, we concluded that although phosphorylation of Ser-97 and Thr-174 are pivotal for Rex-1 function, the substitution for alanine did not result in a significant change in subcellular localization to the cytoplasm.

Since the individual mutations (S97A and T174A) still maintain partial function, it remained a possibility that phosphorylation of both residues are required for optimal biologic activity. To test this hypothesis and determine if there is a functional relationship between Ser-97 and Thr174, we generated and characterized the double mutant for function and protein expression. As shown in Figure $5 \mathrm{~A}$, the double mutant S97A, T174A displayed significantly reduced functional activity as compared to wtRex1 , but a similar activity as the single mutants. Lastly, the nonfunctional Rex-1 mutants were next tested for their capacity to block the biological action of wtRex-1 using the pCgagRxRE-I reporter assay described above. The single mutants (S97A and T174A) or the double mutant (S97A, T174A) displayed a recessive negative phenotype, as the action of wtRex-1 was not significantly altered in their presence (Figure 5B and data not shown).

\section{Discussion}

Phosphorylation plays a key role in regulating the function of cellular and viral proteins $[28,38,39,47,48]$. Previously, it was demonstrated that Rex-1 is a phosphoprotein and that phosphorylation may play a role in Rex-1 function $[39,40]$. It also has been shown that Rex- 1 is essential for efficient viral replication and survival in vivo [45]. Given the importance of this protein in HTLV biology, we sought to understand how Rex-1 function is regulated. Multiple studies have been directed at understanding the importance of phosphorylation in HTLV Rex-2 function $[26,33,41,42,49]$. These studies reported that phosphorylation at the carboxy terminus of Rex-2 is critical for protein stability, shuttling, and cellular localization, all of 


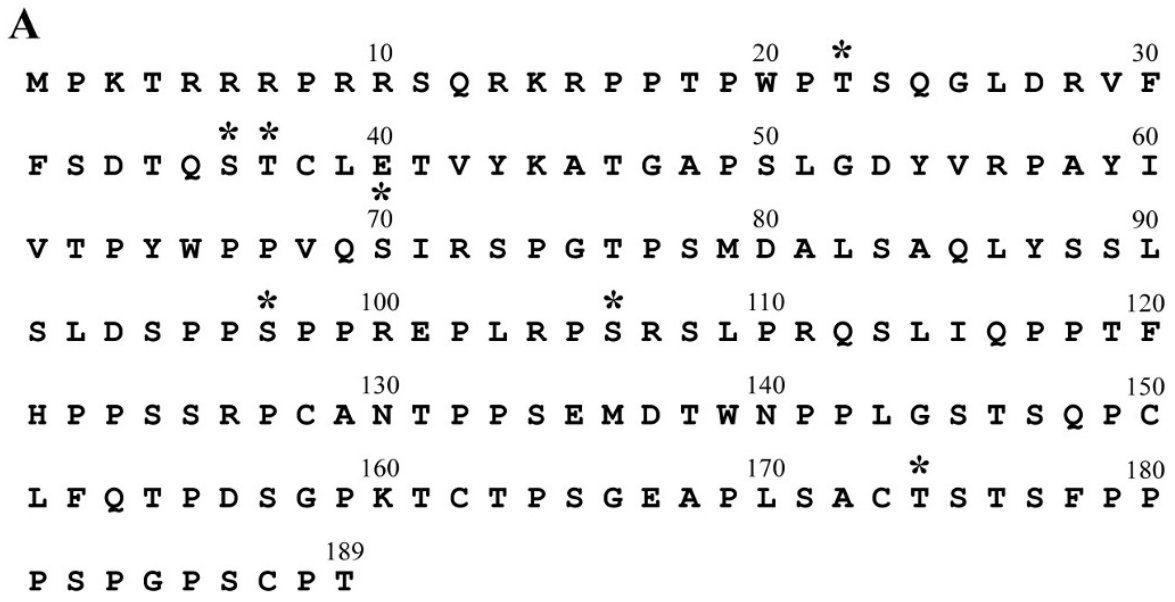

\begin{tabular}{|r|c|c|c|}
\hline & $\begin{array}{c}\text { \# Residues } \\
\text { Mapped/Total }\end{array}$ & $\begin{array}{c}\text { \% Residues } \\
\text { Mapped }\end{array}$ & Phosphorylation Sites \\
\hline Serines (S) & $29 / 29$ & $100 \%$ & S36, S70, S97, S106 \\
\hline Threonines (T) & $19 / 19$ & $100 \%$ & T22, T37, T174 \\
\hline Total amino acids & $189 / 189$ & $100 \%$ & $7 / 189$ \\
\hline
\end{tabular}

\section{B}

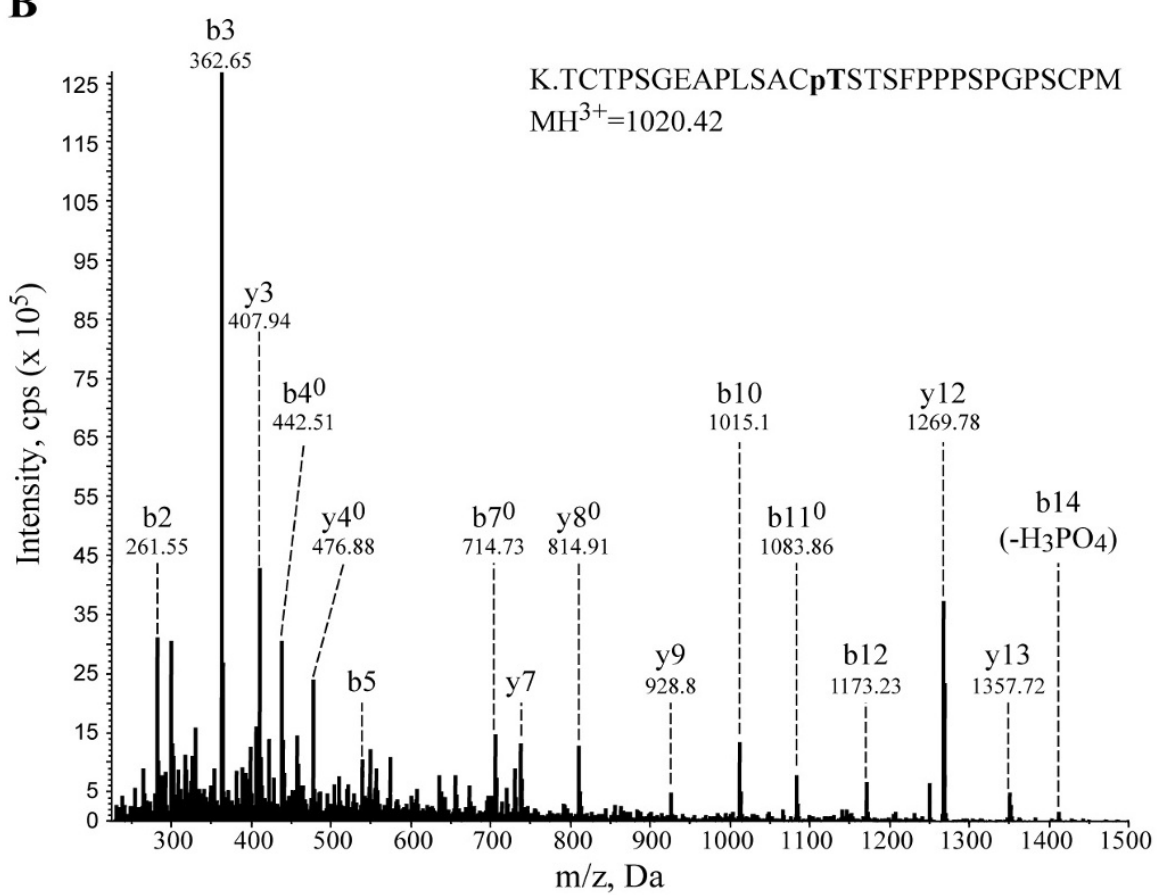

Figure 3

Mapping Rex-I phosphorylation sites by mass spectrometry. (A) A compilation of the results obtained with LC-MS/MS analysis of S-tagged Rex-I. The 189 aa Rex-I protein is depicted with phosphorylation sites identified (*). The table (inset) shows \% total amino acid coverage from LC-MS/MS analysis. (B) A representative MS/MS spectrum of the tryptic phosphopeptide, which identified phosphorylation at Thr- 174 is shown. CID Mass spectrum of m/z $1020.42(3+)$ revealed a 29 aa peptide of $M_{r}$ 3058.23. $B$ and $Y$ ion designations marked with (0) indicate a loss of $\mathrm{H}_{2} \mathrm{O}$ are doubly charged. The presence of the bl0, bl I and bI 2 ions maps the phosphorylation to Thr- I74. The MASCOT peptide score was 82 with an expected score of 0.0028. 


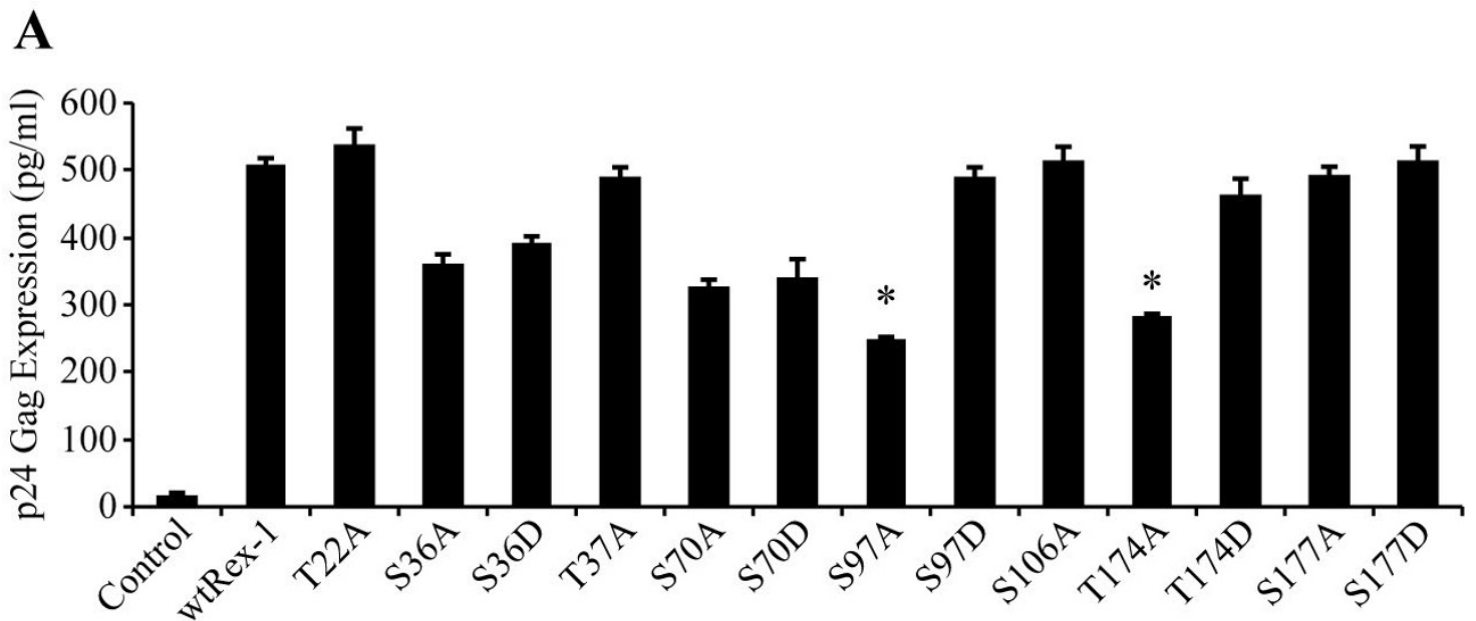

B

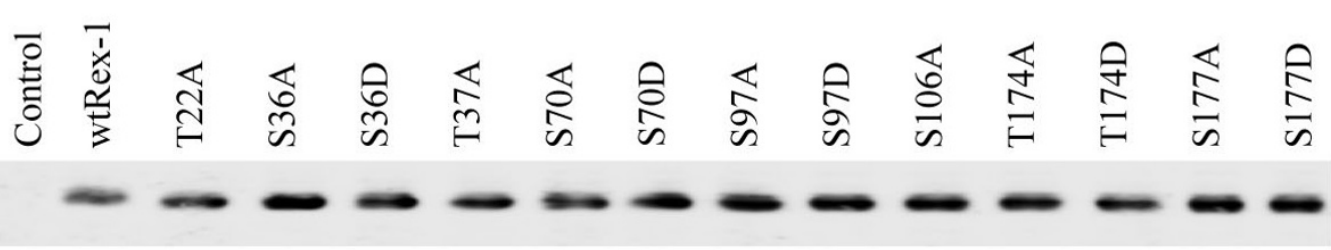

C
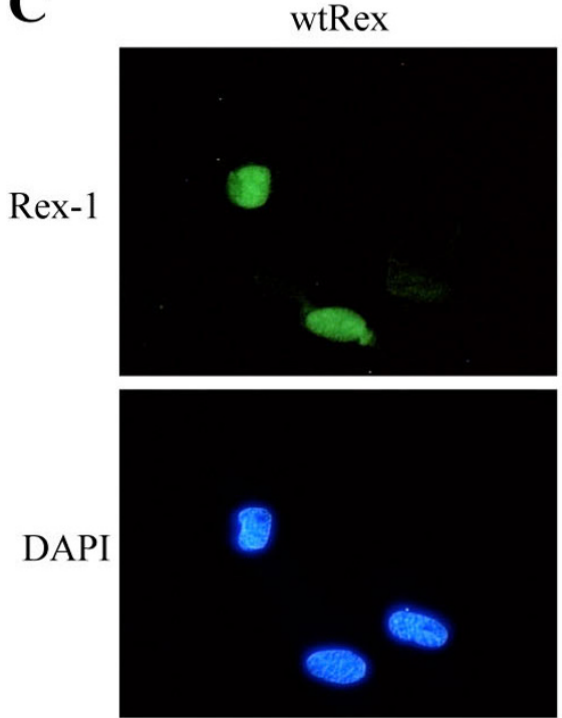

S97A
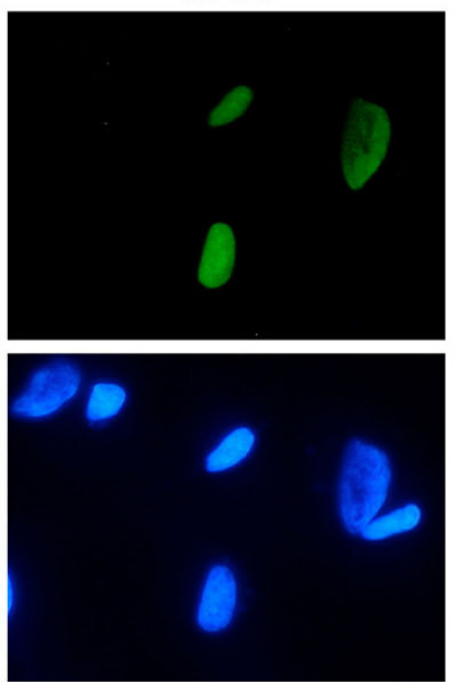

T174A
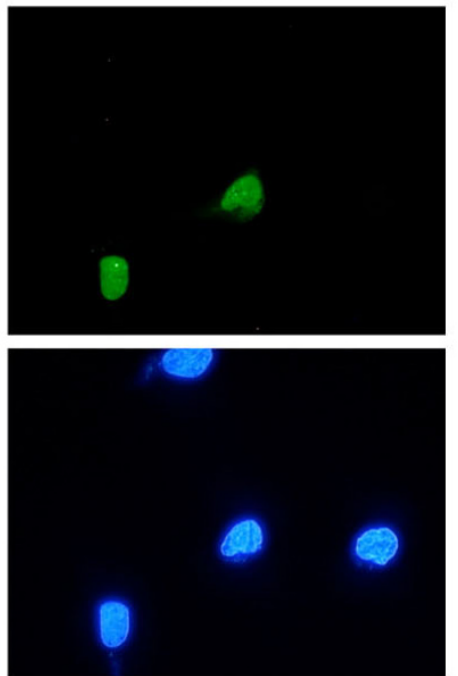

\section{Figure 4}

Mutational analysis of Rex-I phospho-specific mutants. (A) The functional activity of either wtRex-I or Rex-I mutants, as indicated, was determined using the modified HIV p24 Gag reporter assay. The specific amino acid substitution for each Rex-I mutant is shown. 293T cells were transfected with $0.25 \mu \mathrm{g}$ pcTat, $0.5 \mu \mathrm{g}$ PCgagRxRE-I, $0.05 \mu \mathrm{g}$ CMV-luc, and $0 . \mathrm{I} \mu \mathrm{g}$ of wtRex-I or Rex-I mutant plasmids. At $24 \mathrm{~h}$ post-transfection, cells were harvested and assayed for $\mathrm{p} 24 \mathrm{Gag}$. The values represent actual p24 Gag production from a representative experiment performed in triplicate. Error bars indicate standard deviations. T, threonine; S, serine; A, alanine; D, aspartic acid. (B) Western blot analysis of wild-type and Rex-I mutants. Whole cell lysates normalized for transfection efficiency were subjected to Western blot using rabbit Rex-I-specific antisera. Rex-I is indicated. (C) To determine the subcellular localization of the Rex-I mutants, HeLa-Tat cells were transfected with I $\mu g$ of a control plasmid, wtRex-I, or various Rex-I mutants. At 24 hours post-transfection, cells were stained with rabbit Rex-I-specific antisera (Green). Nuclei were stained with DAPI (Blue). 

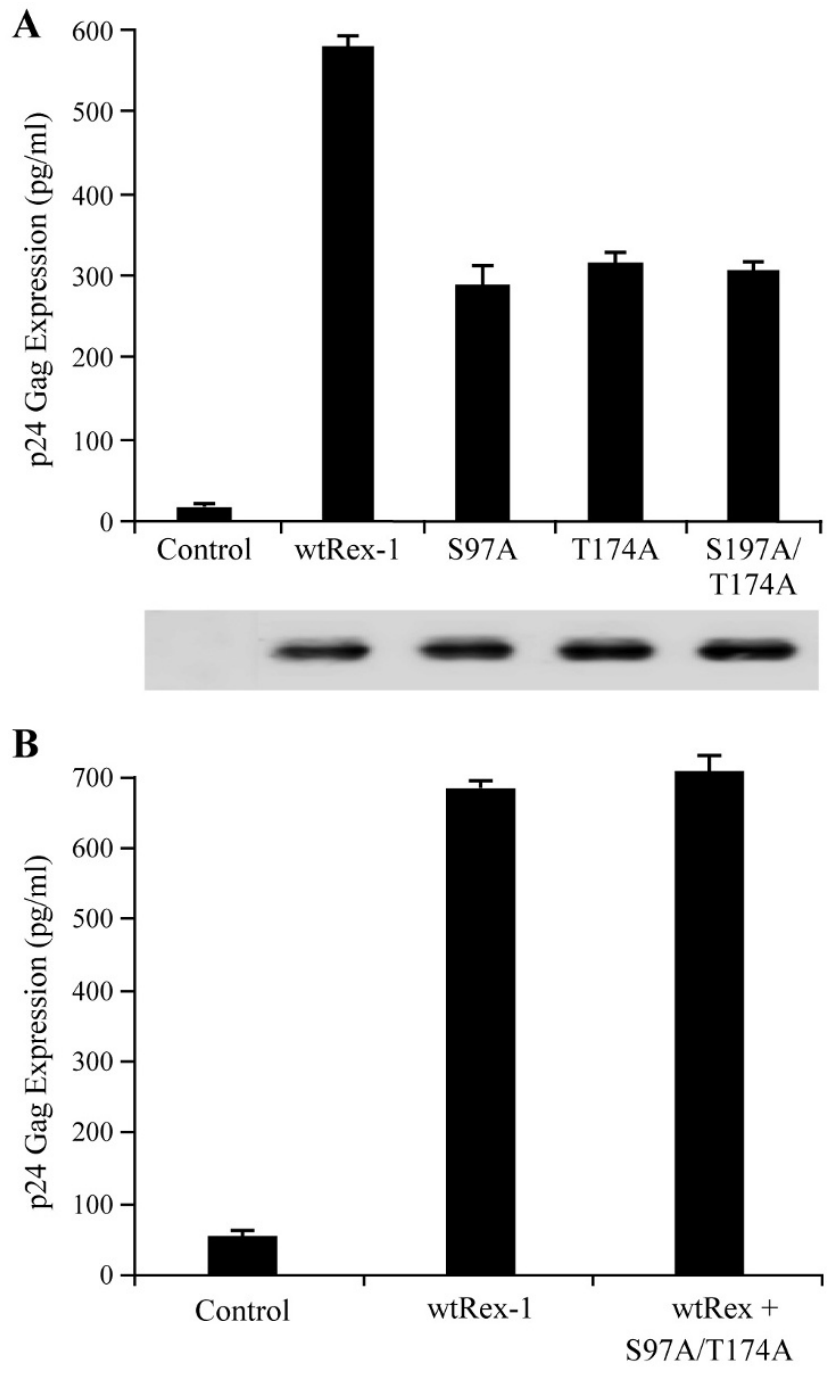

Figure 5

The functional activity of S97A and TI74A single and double mutants. (A) The activity of either wtRex-I or Rex-I mutants, as indicated, was determined using the modified HIV p24 Gag reporter assay. The specific amino acid substitution for each Rex-I mutant is shown. Cells were transfected and Rex activity was determined as described in the legend to Figure 4. The values represent actual p24 Gag production from a representative experiment performed in triplicate. Error bars indicate standard deviations. T, threonine; S, serine; $A$, alanine; $D$, aspartic acid. Whole cell lysates normalized for transfection efficiency were subjected to Western blot (shown below) using rabbit Rex-I-specific antisera. (B) 293T cells were transfected with $0.25 \mu \mathrm{g}$ pcTat, $0.5 \mu \mathrm{g}$ PCgagRxRE-I, $0.05 \mu \mathrm{g}$ CMV-luc, and $0.1 \mu \mathrm{g}$ of wtRex-I or $0.1 \mu \mathrm{g}$ of wtRex-I + $0.2 \mu \mathrm{g}$ of S97A, TI74A Rex-I mutant plasmid. Cell lysates were prepared 24 hours post-transfection and p24 Gag levels were determined by HIV-I p24 Gag ELISA. Rex-I functional assay reveals that the double mutant (S97A, TI74A) does not inhibit the function of wtRex-I and thus is not a trans dominant protein. which are positively regulated through phosphorylation $[28,33,49]$. There have been some efforts aimed at determining the role of phosphorylation in the regulation of HTLV Rex-1 $[39,40]$. The first studies used thin layer chromatography and tryptic peptide analysis. The studies reported that the native protein was phosphorylated mainly on serine and threonine. Subsequently, it was reported that Rex-1 was phosphorylated on three residues; Ser-70, Ser-177, and Thr-174. This group also speculated that protein kinase $\mathrm{C}$ may play a role in Rex-1 phosphorylation, which was supported by drug studies using the more global kinase inhibitor H-7 [40]. Neither study could conclusively identify all phosphorylation sites within Rex-1, nor were any of the sites further tested for their biological relevance.

In the current study, we were able to not only identify phosphorylated Rex-1, but also assign phosphorylation to site-specific residues by peptide sequencing using tandem mass spectrometry. Consistent with previous reports, we confirmed that Rex-1 is phosphorylated predominantly on serine and threonine residues. We report the identification of five novel phosphorylation sites, Thr-22, Ser-36, Thr-37, Ser-97, and Ser-106 and also confirmed the phosphorylation on Ser-70 and Thr-174. Furthermore, we identified specific phosphorylation sites that are critical for Rex-1 function in vivo. These phosphorylation sites specifically include Ser-97 and Thr-174. We previously showed that phosphorylation of a specific residue of Rex2 at the carboxy terminus (Ser-151) is important for proper protein nuclear localization [28,33]. Evaluation of the functionally disrupted substitution mutants S97A and T174A for subcellular localization revealed no difference when compared to wild-type. It is important to note that Ser-97 falls within the previously characterized central core activation domain/nuclear export signal [50], and that phosphorylation of this residue may be pivotal for proper Rex-1 function. Previous studies of both HIV-1 Rev and HTLV-1 Rex showed that mutations within the NES interfere with the ability of these proteins to associate with CRM1, a cellular protein that belongs to the importin $\beta$ family and functions as a nuclear export receptor for NEScontaining proteins and the Rev- and Rex-dependent viral mRNAs encoded by these complex retroviruses [29,5054]. An important direction for future studies is to evaluate whether the non-functional mutants are defective for CRM1 binding or the efficient interaction with the Rexresponse element RNA target.

Thr-174, which is located in the carboxy terminus of Rex1 , was identified as a critical phosphorylation site. It was shown previously that Ser-151, located in the carboxy terminus of Rex-2, is a key phosphorylation site important for Rex-2 function in vivo $[26,33]$. We also demonstrated 
that Rex-1 and Rex-2 share a similar stability domain located within their carboxy terminus [28]. We hypothesized that phosphorylation of Thr-174 of Rex-1 (Fig. 4B) could play a similar role in regulating Rex-1 function similar to Rex-2 Ser-151. Further C-terminal comparison analysis is on-going to elucidate further homology between these two related proteins.

One previous study identified phosphorylation on Ser177 of Rex-1 [39]. Throughout our studies, we were unable to confirm this finding, but we did identify multiple new sites. One explanation for why these new phosphorylation sites were not identified in the earlier studies could be that the high performance liquid chromatography fraction procedure used may have resulted in a loss of other phosphopeptides within the protein. The selective loss of phosphopeptides can result from the addition of a phosphate group, thus reducing hydrophobicity, which may cause failure of the protein to be retained on the reversephase material used in purification [55]. An additional consideration is that the previous study analyzed Rex-1 protein derived from a different cell type (COS-7 or HTLV1 transformed T-cell lines), which may produce alternative post-translational modification patterns when compared to 293 T cells. Although it is not without its own caveat and limitations, LC-MS/MS provides a more robust method for the comprehensive mapping of phosphorylation sites [55-58].

\section{Conclusion}

In summary, our data indicate that phosphorylation of specific residues regulates Rex-1 function. Utilizing a combination of affinity purification, liquid chromatography tandem mass spectrometry, and site-directed mutational analysis we identified two phosphorylated residues, Ser97 and Thr-174 that are critical for Rex-1 function. Ongoing research in our lab is focused on comparative studies to better characterize the homology of the carboxy terminus of Rex-1 and Rex-2. These studies are focused on uncovering Rex cellular binding partners and kinase(s) and their functional relationship in order to better understand how phosphorylation regulates Rex-1 function. These studies will enable us to determine the differences between the two related proteins and perhaps gain insight into the distinct pathology following HTLV-1 and HTLV-2 infection.

\section{Methods \\ Cells}

$293 \mathrm{~T}$ and HeLa-Tat cells were maintained at $37^{\circ} \mathrm{C}$ in a humidified atmosphere of $5 \% \mathrm{CO}_{2}$ in air in Dulbecco's modified Eagle medium. The medium was supplemented with $10 \%$ fetal bovine serum (FBS), $2 \mathrm{mM}$ glutamine, penicillin $(100 \mathrm{U} / \mathrm{ml})$, and streptomycin $(100 \mu \mathrm{g} / \mathrm{ml})$.

\section{Mammalian Expression Plasmid}

The Rex-1 expression vector SE356, which contains the HTLV-1 tax/rex cDNA expressed from the cytomegalovirus (CMV) immediate-early gene promoter, was described previously [14,59]. The S-tagged Rex-1 expression vector S-Rex-1 was constructed by inserting the HTLV-1 tax/rex open reading frame from SE356 into pTriEx4-Neo (Novagen, Madison, WI) in-frame with the amino-terminal Histag and S-tag via SmaI and BamHI. All generated rex expression vectors contained a previously described mutation in the overlapping tax reading frame (F4Term), which had no effect on the Rex-1 amino acid sequence, but severely truncated Tax-1, completely knocking out expression and function [60]. The various rex-1 targeted mutations were generated using the QuikChange ${ }^{\mathrm{TM}}$ sitedirected mutagenesis kit (Stratagene, La Jolla, CA) to introduce targeted amino acid changes. All mutations were confirmed by DNA sequence analysis and vector expression was verified by transfection and Western blot analysis. The human immunodeficiency virus type 1 (HIV-1) Tat expression vector, pcTat, Rex-1 reporter plasmid (pCgagRxRE-I) and the CMV-luciferase (firefly) transfection efficiency control were described previously [59].

\section{Rex-I Functional Reporter Assay}

The Rex-1 functional assay was performed as described previously with slight modification [26]. Briefly, $0.1 \mu \mathrm{g}$ Rex-1 cDNA expression plasmid was co-transfected into $293 \mathrm{~T}$ cells with $0.05 \mu \mathrm{g}$ of CMV-luc, $0.25 \mu \mathrm{g}$ of pcTat, and $0.5 \mu \mathrm{g}$ of Rex-1 reporter plasmid pCgag-RxRE-I using Lipofectamine Reagent (Invitrogen, Carlsbad, CA). Cell lysates were prepared at $24 \mathrm{~h}$ post-transfection in Passive Lysis Buffer (Promega, Madison, WI) with a protease inhibitor mixture (Roche Applied Science Indianapolis, IN) on ice for $30 \mathrm{~min}$. Luciferase activity was determined to control for transfection efficiency. HIV-1 p24 Gag levels in the cellular lysates were determined by ELISA (ZeptoMetrix, Buffalo, NY). All transfection experiments were performed in triplicate in three independent experiments and presented as an average with standard deviation.

\section{Immunoblot and Immunofluorescence Analysis}

Cell lysates were prepared $24 \mathrm{~h}$ post-transfection in Passive Lysis Buffer (Promega, Madison, WI) with a protease inhibitor mixture (Roche Applied Science, Indianapolis, IN) on ice for $30 \mathrm{~min}$. After centrifugation, total protein concentrations were determined by Bradford protein assay (Bio-Rad, Hercules, CA). To detect Rex-1, $50 \mu \mathrm{g}$ of total cell lysates from transfected cells was separated by SDS-PAGE (12\%) and transferred to a nitrocellulose membrane (Schleicher \& Schuell Biosciences, Keene, $\mathrm{NH}$ ). Proteins were visualized using polyclonal rabbit $\alpha$ Rex-1 specific antisera and the enhanced chemiluminescence (ECL) Western blot analysis system (Santa Cruz Biotechnology, Santa Cruz, CA). Subcellular localization of 
Rex-1 was performed as previously described [61] with slight modification. HeLa-Tat cells were transfected with 1 $\mu \mathrm{g}$ of control plasmid or S-Rex-1. At $24 \mathrm{~h}$ post-transfection, cells were washed and fixed in PBS containing 2\% paraformaldehyde and permeabilized in PBS containing $0.2 \%$ Triton X-100 and $0.5 \%$ FBS for 15 min at $4{ }^{\circ} \mathrm{C}$. Cells were incubated in blocking buffer $(0.5 \%$ FBS and $2 \mathrm{mg} / \mathrm{ml}$ human IgG) for $30 \mathrm{~min}$ at room temperature. Staining was conducted in blocking buffer with rabbit $\alpha$-Rex-1 specific antisera followed by secondary antibody conjugated to FITC Alexa 488 (Molecular Probes, Eugene, OR). Nuclear staining was performed using 4'6-diamidino-2phenylindole (DAPI) Slow Fade Gold (Invitrogen, Carlsbad, CA). Fluorescence was visualized on an epifluorescence microscope (Olympus, Melville, NY) and digital images were taken using the Optronics Imaging System (Goleta, CA).

\section{Purification of Rex-I Protein}

Protein purification was performed as described previously with a slight modification [43]. Briefly, cell lysate $(1.5 \mathrm{ml})$ was incubated with a $75 \mu \mathrm{l}$ bed volume of S-protein agarose (Novagen) overnight at $4^{\circ} \mathrm{C}$, washed twice with a high salt modified RIPA buffer $(0.05 \mathrm{M}$ Tris-HCl, pH 8.0, 0.1\% SDS, $1 \%$ Triton X-100, $1.0 \mathrm{M} \mathrm{NaCl}, 0.01 \mathrm{M}$ EDTA) and twice with a low salt modified RIPA buffer (0.05 M Tris-HCl, pH 8.0, 0.1\% SDS, 1\% Triton X-100, $150 \mathrm{mM} \mathrm{NaCl}$ ). One hundred $\mu \mathrm{l}$ SDS loading dye with $\beta$ mercaptoethanol was added to the washed beads followed by boiling for $2 \mathrm{~min}$. Samples were electrophoresed on a $12 \%$ SDS one-dimensional polyacrylamide gel and visualized by Coomassie blue staining. The S-tagged Rex1 band was excised from the gel for further proteomic analysis.

\section{Mass Spectrometry Analysis}

LC-MS/MS analysis was performed as described previously with slight modification [43]. Briefly, the S-tagged Rex-1 protein band was excised from a 1-D polyacrylamide gel, cut into 1-2 mm cubes, washed three times with $500 \mu \mathrm{l}$ ultra-pure water and incubated in 100\% acetonitrile for $45 \mathrm{~min}$. Samples were reduced with $50 \mathrm{mM}$ DTT at $56^{\circ} \mathrm{C}$ for $45 \mathrm{~min}$ and then alkylated with $55 \mathrm{mM}$ iodoacetamide for $1 \mathrm{~h}$ at room temperature. The material was dried in a speed-vac, rehydrated in a $12.5 \mathrm{ng} / \mu \mathrm{l} \mathrm{mod-}$ ified sequencing grade trypsin solution (Promega, Madison, WI) and incubated in an ice bath for 40-45 min. The excess trypsin solution was removed and replaced with $40-50 \mu \mathrm{l}$ of $50 \mathrm{mM}$ ammonium bicarbonate, $10 \%$ acetonitrile ( $\mathrm{pH} 8.0$ ), and the mixture was incubated overnight at $37^{\circ} \mathrm{C}$. Elastase digests were performed as described for trypsin at an enzyme concentration of 15 $\mathrm{ng} / \mu \mathrm{l}$, but were performed without acetonitrile in the reaction buffer. Peptides were extracted twice with $25 \mu \mathrm{l} 50 \%$ acetonitrile, 5\% formic acid and dried in a speed-vac.
Digests were resuspended in $20 \mu \mathrm{l}$ Buffer A (5\% acetonitrile, $0.1 \%$ formic Acid, $0.005 \%$ heptafluorobutyric acid) and 3-6 $\mu$ l were loaded onto a $12 \mathrm{~cm} \times 0.075 \mathrm{~mm}$ fused silica capillary column packed with $5 \mu \mathrm{M}$ diameter C-18 beads (The Nest Group, Southboro, MA) using an N2 pressure vessel at 1100 psi. Peptides were eluted over 55 min by applying a $0-80 \%$ linear gradient of Buffer B (95\% acetonitrile, $0.1 \%$ formic acid, $0.005 \%$ HFBA) at a flow rate of $150 \mu \mathrm{l} / \mathrm{min}$ with a pre-column flow splitter resulting in a final flow rate of $\sim 200 \mathrm{nl} / \mathrm{min}$ directly into the source. In some cases, the gradient was extended to $150 \mathrm{~min}$ to acquire more MS/MS spectra. An $\mathrm{LTQ}^{\mathrm{TM}}$ Linear Ion Trap (ThermoFinnigan, San Jose, CA) was run in an automated collection mode with an instrument method composed of a single segment and five data-dependent scan events with a full MS scan followed by four MS/MS scans of the highest intensity ions. Normalized collision energy was set at 35 , activation Q was 0.250 with minimum full scan signal intensity at $1 \times 10^{5}$ with no minimum $\mathrm{MS}^{2}$ intensity specified. Dynamic exclusion was turned on and utilized a three minute repeat count of 2 with the mass width set at $1.0 \mathrm{~m} / \mathrm{z}$. Sequence analysis was performed with TurboSEQUEST ${ }^{\mathrm{TM}}$ (ThermoFinnigan, San Jose, CA) or MASCOT (Matrix Sciences, London GB) using an indexed Human subset database of the nonredundant protein database from National Center for Biotechnology Information (NCBI) web site http:// www.ncbi.nlm.nih.gov/.

\section{Competing interests}

The authors declare that they have no competing interests.

\section{Authors' contributions}

MK generated all the clones, carried out functional assays, purified the protein, and drafted the manuscript. RD characterized the Rex non functional mutants for trans-dominant activity and helped with editing the manuscript. MW performed the LC-MS/MS analysis and helped interpret the data. OJS helped in finalizing the manuscript and provided important input on the design of the protein expression and purification. PLG conceived the study, participated in its coordination, helped in drafting and finalizing the manuscript. All authors read and approved the final manuscript.

\section{Acknowledgements}

We thank Kate Hayes-Ozello for editorial comments on the manuscript and Tim Vogt for figure preparations. This work was supported by a grant from the National Institutes of Health (CAI00730) to PLG.

\section{References}

I. Lairmore M, Franchini G: Human T-Cell Leukemia Virus Types I and 2. In Fields Virology. Volume 5th Volume Chapter 56. Edited by: Fields B, Knipe D, Howley P, Chanock R, Monath T, Melnick J, Roizman B, Straus S. Philadelphia, PA USA.: Lippincott Williams, and Wilkins; 2007:207l-2106.

2. Wolfe ND, Heneine W, Carr JK, Garcia AD, Shanmugam V, Tamoufe U, Torimiro JN, Prosser AT, Lebreton M, Mpoudi-Ngole E, et al.: 
Emergence of unique primate T-lymphotropic viruses among central African bushmeat hunters. Proc Natl Acad Sc USA 2005, 102:7994-7999.

3. Calattini S, Chevalier SA, Duprez R, Bassot S, Froment A, Mahieux R, Gessain A: Discovery of a new human T-cell lymphotropic virus (HTLV-3) in Central Africa. Retrovirology 2005, 2:30.

4. Switzer WM, Salemi M, Qari SH, Jia H, Gray RR, Katzourakis A, Marriott SJ, Pryor KN, Wolfe ND, Burke DS, et al: Ancient, independent evolution and distinct molecular features of the novel human T-lymphotropic virus type 4. Retrovirology 2009, 6:9.

5. Ferreira OJ, Planelles V, Rosenblatt J: Human T-cell leukemia viruses: epidemiology, biology, and pathogenesis. Blood Rev 1997, II:91-104.

6. Osame M, Igata A, Matsumoto M, Usuku K, Izumo S, Kosaka K: HTLV-I associated myelopathy: A report of 85 cases. Ann Neurol 1987, 22:116.

7. Yoshida M: Discovery of HTLV-I, the first human retrovirus, its unique regulatory mechanisms, and insights into pathogenesis. Oncogene 2005, 24:593I-5937.

8. Rosenblatt JD, Giorgi JV, Golde DW, Ezra JB, Wu A, Winberg CD Glaspy J, Wachsman W, Chen IS: Integrated human T-cell leukemia virus II genome in CD8 + T cells from a patient with "atypica" hairy cell leukemia: evidence for distinct $T$ and $B$ cell lymphoproliferative disorders. Blood 1988, 7 I:363-369.

9. Berger JR, Svenningsson A, Raffanti S, Resnick L: Tropical spastic paraparesis-like illness occurring in a patient dually infected with HIV-I and HTLV-II. Neurology 1991, 4I:5-7.

10. Hjelle B, Appenzeller O, Mills R, Alexander S, Torrez-Martinez N, Jahnke R, Ross G: Chronic neurodegenerative disease associated with HTLV-II infection. Lancet 1992, 339:645-646.

II. Harrington WJ Jr, Sheremata W, Hjelle B, Dube DK, Bradshaw P, Foung SK, Snodgrass S, Toedter G, Cabra IL, Poiesz B: Spastic ataxia associated with human $\mathrm{T}$-cell lymphotropic virus type II infection. Annals Neurol 1993, 7:1031-1034.

12. Poiesz B, Dube D, Dube S, Love J, Papsidero L, Uner A, Hutchinson R: HTLV-II-associated cutaneous T-cell lymphoma in a patient with HIV-I infection. N Engl J Med 2000, 342:930-936.

13. Cann AJ, Rosenblatt JD, Wachsman W, Shah NP, Chen ISY: Identification of the gene responsible for human T-cell leukemia virus transcriptional regulation. Nature 1985, 3 | 8:57|-574.

14. Felber BK, Paskalis H, Kleinman-Ewing C, Wong-Staal F, Pavlakis GN: The $\mathrm{pX}$ protein of $\mathrm{HTLV}-\mathrm{I}$ is a transcriptional activator of its long terminal repeats. Science 1985, 229:675-679.

15. Inoue JI, Yoshida M, Seiki M: Transcriptional (p40x) and posttranscriptional (p27xIII) regulators are required for the expression and replication of human T-cell leukemia virus type I genes. Proc Natl Acad Sci USA 1987, 84:3653-3657.

16. Mulloy JC, Kislyakova T, Cereseto A, Casareto L, LoMonico A, Fullen J, Lorenzi MV, Cara A, Nicot C, Giam C, Franchini G: Human T-cell lymphotropic/leukemia virus type I Tax abrogates p53induced cell cycle arrest and apoptosis through its CREB/ ATF functional domain. J Virol 1998, 72:8852-8860.

17. Ressler S, Morris GF, Marriott S): Human T-cell leukemia virus type I Tax transactivates the human proliferating cell nuclear antigen promoter. J Virol 1997, 71: I 18I-I I90.

18. Schmitt I, Rosin O, Rohwer P, Gossen M, Grassmann R: Stimulation of cyclin-dependent kinase activity and $G I$ to $S$ phase transition in human lymphocytes by the human T-cell leukemia/ lymphotropic virus type I tax protein. J Virol I998, 72:633-640.

19. Boxus M, Twizere JC, Legros S, Dewulf JF, Kettmann R, Willems L: The HTLV-I Tax interactome. Retrovirology 2008, 5:76.

20. Ramadan E, Ward M, Guo X, Durkin SS, Sawyer A, Vilela M, Osgood C, Pothen A, Semmes OJ: Physical and in silico approaches identify DNA-PK in a Tax DNA-damage response interactome. Retrovirology 2008, 5:92.

21. Robek MD, Ratner L: Immortalization of CD4+ and CD8+ Tlymphocytes by human T-cell leukemia virus type I Tax mutants expressed in a functional molecular clone. J Virol 1999, 73:4856-4865

22. Ross TM, Narayan M, Fang ZY, Minella AC, Green PL: Tax transactivation of both NF $K B$ and CREB/ATF is essential for Human T-cell leukemia virus type 2-mediated transformation of primary human T-cells. J Virol 2000, 74:2655-2662.

23. Wycuff DR, Marriott SJ: The HTLV-I Tax Oncoprotein:Hypertasking at the molecular level. Front Biosci 2005, 10:620-642.
24. Ballaun C, Farrington GR, Dobrovnik M, Rusche J, Hauber J, Bohnlein $E$ : Functional analysis of human T-cell leukemia virus type I Rex-response element: Direct RNA binding of Rex protein correlates with in vivo binding activity. I Virol |99|, 65:4408-44I3.

25. Kusuhara K, Anderson M, Pettiford SM, Green PL: Human T-cell leukemia virus type 2 Rex protein increases stability and promotes nuclear to cytoplasmic transport of gag/pol and env RNAs. J Virol 1999, 73:8 I I2-8I I9.

26. Narayan M, Kusuhara K, Green PL: Phosphorylation of two serine residues regulates human T-cell leukemia virus type 2 Rex function. J Virol 200I, 75:8440-8448.

27. Younis I, Green PL: The human T-cell leukemia virus Rex protein. Frontiers in Biosciences 2005, 10:43 I-445

28. Xie L, Kesic M, Yamamoto B, Li M, Younis I, Lairmore MD, Green PL: HTLV-2 Rex carboxy terminus is an inhibitory/stability domain that regulates Rex functional activity and viral replication. J Virol 2009, 83:5232-5243.

29. Bogerd H, Greene WC: Dominant negative mutants of human T-cell leukemia virus type I Rex and human immunodeficiency virus type I Rev fail to multimerize in vivo. J Virol I993, 67:2496-2502.

30. Bogerd HP, Huckaby GL, Ahmed YF, Hanly SM, Greene WC: The type I human T-cell leukemia virus (HTLV-I) Rex trans-activator binds directly to the HTLV-I Rex and the type I human immunodeficiency virus Rev RNA response elements. Proc Natl Acad Sci USA I99I, 88:5704-5708.

31. Hammes SR, Green WC: Multiple arginine residues within the basic domian of HTLV-I Rex are required for specific RNA binding and function. Virology 1993, 193:4I-49.

32. Hope TJ, Bond BL, McDonald B, Klein NP, Parslow TG: Effector domains of human immunodeficiency virus type I Rev and human T-cell leukemia virus type I Rex are functionally interchangeable and share an essential peptide motif. J Virol 199|, 65:600|-6007.

33. Narayan M, Younis I, D'Agostino DM, Green PL: Functional domain structure of human T-cell leukemia virus type $\mathbf{2}$ Rex. J Virol 2003, 77: $12829-12840$.

34. Palmeri D, Malim MH: The human T-cell leukemia virus type I post-transcriptional trans-activator Rex contains a nuclear export signal. J Virol 1996, 70:6442-6445.

35. Rimsky L, Duc Dodon M, Dixon EP, Greene WC: Trans-dominant inactivation of HTLV-I and HIV-I gene expression by mutation of the HTLV-I Rex transactivator. Nature 1989 , 34I:453-456

36. Siomi H, Shida H, Nam SH, Nosaka T, Maki M, Hatanaka M: Sequence requirements for nucleolar localization of human $T$ cell leukemia virus type I $\mathrm{pX}$ protein, which regulates viral RNA processing. Cell 1988, 55:197-209.

37. Weichselbraun I, Farrington GK, Rusche JR, Bohnlein E, Hauber J: Definition of human immunodeficiency virus type I Rev and human T-cell leukemia virus type I Rex protein activation domain by functional exchange. J Virol 1992, 66:2583-2587.

38. Tootle TL, Rebay I: Post-translational modifications influence transcription factor activity: a view from the ETS superfamily. Bioessays 2005, 27:285-298.

39. Adachi Y, Copeland TD, Takahashi C, Nosaka T, Ahmed A, Oroszlan S, Hatanaka M: Phosphorylation of the Rex protein of human T-cell leukemia virus type I. J Biol Chem 1992, 267:2 I977-2 I98I.

40. Adachi $Y$, Nosaka T, Hatanaka M: Protein kinase inhibitor $\mathbf{H - 7}$ blocks accumulation of unspliced mRNA of human T-cell leukemia virus type I (HTLV-II). Biochem Biophys Res Comm 1990, 169:469-475.

4I. Green PL, Xie Y, Chen ISY: The Rex proteins of human T-cell leukemia virus type-II differ by serine phosphorylation. J Virol 1991, 65:546-550.

42. Green PL, Yip MT, Xie Y, Chen ISY: Phosphorylation regulates RNA binding by the human T-cell leukemia virus rex protein. J Virol 1992, 66:4325-4330.

43. Durkin SS, Ward MD, Fryrear KA, Semmes OJ: Site-specific phosphorylation differentiates active from inactive forms of the human T-cell leukemia virus type I Tax oncoprotein. J Biol Chem 2006, 28I:31705-317I2.

44. Ross TM, Minella AC, Fang ZY, Pettiford SM, Green PL: Mutational analysis of human T-cell leukemia virus type 2 Tax. J Virol 1997, $71: 89 \mid 2-8917$. 
45. Ye J, Sileverman L, Lairmore MD, Green PL: HTLV-I Rex is required for viral spread and persistence in vivo but is dispensable for cellular immortalization in vitro. Blood 2003, 1 02:3963-3969.

46. Kim JS, Raines RT: Ribonuclease S-peptide as a carrier in fusion proteins. Protein Science 1993, 2:348-356.

47. Joseph JD, Yeh ES, Swenson KI, Means AR, Winkler: The peptidylprolyl isomerase Pin I. Prog Cell Cycle Res 2003, 5:477-487.

48. Lu KP, Zhou XZ: The prolyl isomerase PINI: a pivotal new twist in phosphorylation signalling and disease. Nat Rev Mol Cell Biol 2007, 8:904-916.

49. Kesic M, Ward MD, Semmes OJ, Green PL: Site-specific phosphorylation regulates human T-cell leukemia virus type 2 Rex function in vivo. J Virol 83( I 7):8859-68.

50. Hofer L, Weichselbraun I, Quick S, Farrington GK, Bohnlein E, Hauber J: Mutational analysis of the human T-cell leukemia virus type I trans-acting rex gene product. J Virol I99I, 65:3379-3383.

5I. Böhnlein SF, Pirker FP, Hofer L, Bachmayer H, Böhnlein E, Hauber J: Transdominant repressors for human $T$-cell leukeina virus type I Rex and human immunodeficiency virus type I Rev function. / Virol 1991, 65:81-88.

52. Malim MH, Bohnlein S, Hauber J, Cullen BR: Functional dissection of the HIV-I Rev transactivator-derivation of trans-dominant repressor of $\operatorname{Rev}$ function. Cell 1989, 58:205-2|4.

53. Venkatesh LK, Chinnadurai G: Mutants in a conserved region near the carboxy-terminus of HIV-I Rev identify functionally important residues and exhibit a dominant negative phenotype. Virology 1990, I 78:327-330.

54. Hakata $Y$, Umemoto $T$, Matsushita $S$, Shida $H$ : Involvement of human CRMI (exportin I) in the export and multimerization of the Rex protein of human T-cell leukemia virus type I. J Virol 1998, 72:6602-6607.

55. Neubauer G, Mann M: Mapping of phosphorylation sites of gelisolated proteins by nanoelectrospray tandem mass spectrometry: potentials and limitations. Anal Chem 1999, 7 I:235-242.

56. Loyet KM, Stults JT, Arnott D: Mass spectrometric contributions to the practice of phosphorylation site mapping through 2003: a literature review. Mol Cell Proteomics 2005, 4:235-245.

57. Arnott D, Gawinowicz MA, Grant RA, Neubert TA, Packman LC Speicher KD, Stone K, Turck CW: ABRF-PRG03: phosphorylation site determination. I Biomol Tech 2003, | 4:205-2I 5.

58. McLachlin DT, Chait BT: Analysis of phosphorylated proteins and peptides by mass spectrometry. Curr Opin Chem Biol 200I, 5:591-602.

59. Ye J, Xie L, Green PL: Tax and overlapping Rex sequences do not confer the distinct transformation tropisms of HTLVand HTLV-2. J Virol 2003, 77:7728-7735.

60. Ross TM, Pettiford SM, Green PL: The tax gene of human T-cell leukemia virus type $\mathbf{2}$ is essential for transformation of human T lymphocytes. J Virol 1996, 70:5194-5202.

61. Voss OH, Batra S, Kolattukudy SJ, Gonzalez-Mejia ME, Smith JB, Doseff $\mathrm{Al}$ : Binding of caspase- 3 prodomain to heat shock protein 27 regulates monocyte apoptosis by inhibiting caspase-3 proteolytic activation. J Biol Chem 2007, 282:25088-25099.
Publish with Bio Med Central and every scientist can read your work free of charge

"BioMed Central will be the most significant development for disseminating the results of biomedical research in our lifetime. "

Sir Paul Nurse, Cancer Research UK

Your research papers will be:

- available free of charge to the entire biomedical community

- peer reviewed and published immediately upon acceptance

- cited in PubMed and archived on PubMed Central

- yours - you keep the copyright 